\title{
HARMFUL EFFECTS OF FORMALIN ON FIRST MBBS STUDENTS: A QUESTIONNAIRE STUDY
}

\author{
Abha Bharadwaja1, Garima Bafna ${ }^{2}$ \\ 1 Professor, Department of Anatomy, Jawaharlal Nehru Medical College, Ajmer. \\ 2Professor, Department of Physiology, Jawaharlal Nehru Medical College, Ajmer.
}

\section{ABSTRACT}

Formalin is extensively used preservative for cadavers in Department of Anatomy. Formalin after evaporation from embalmed bodies turns into fumes and is responsible for harmful effects. The present study was conducted in the Department of Anatomy at JLN Medical College, Ajmer. A questionnaire containing 15 symptoms arising due to inhalation of formalin fumes was prepared and distributed to 50 students. The most distressing symptom was congestion/running nose and redness of eyes/itching of eyes. The harmful effects of formalin can be reduced by some preventive measures like good exhaust ventilation by reducing the concentration of formalin in embalming fluid or using alternative for formalin in the form of phenoxyethanol.

\section{KEYWORDS}

Anatomy, Dissection, Dissection Hall, Formaldehyde, Cadavers.

HOW TO CITE THIS ARTICLE: Bharadwaja A, Bafna G. Harmful effects of formalin on first mbbs students: a questionnaire study. J. Evolution Med. Dent. Sci. 2016;5(56):3823-3825, DOI: 10.14260/jemds/2016/875

\section{INTRODUCTION}

To prepare cadavers for dissection in anatomy hall needs a fixative so as to preserve the dead body for this purpose formalin is used, which is a colourless, irritative fluid that contain $37 \%$ of formaldehyde in water and is widely used as a preserving agent in biological specimen. At medical and dental colleges, formalin has been used for years to preserve cadavers. Formaldehyde was discovered in 1856 by the British chemist, August van Hobmann.(1) It is a noxious flammable gas extremely soluble in water, recently, it has attracted much attention due to its health hazards.

Primary route of exposure to is by inhalation, where it is absorbed by the lungs and also through gastrointestinal tract and too much lesser extent through the skin.(2) Anatomists, technicians in biological science laboratories \& medical school students in dissection hall are regularly exposed to formaldehyde. The level of exposure to formalin depends on the time spent in the anatomy practical hall \& museums working conditions there \& type of embalming performed. A good ventilated dissection hall can reduce the concentration of formalin vapour and thus its toxicity.

To prepare a cadaver in medical school for dissection, it is embalmed via the infusion of chemical substances into the body tissues that include formalin (Contains formaldehyde), alcohol, glycerine, carbolic acid \& dye.(3) These substances have specific roles like fixation, preservation, denaturation, disinfection, and maintenance of integrity of anatomic relations required for dissection purpose.(4) It is generally infused via femoral arteries. The formulation for the preparation of embalming fluid varies. It depends on the laboratory and other factors like size, extent of oedema, and stage of decomposition of the cadaver. In the present study, the cadavers are preserved with 1:3 (Formaldehyde:water) concentration of fluid.

Financial or Other, Competing Interest: None.

Submission 13-05-2016, Peer Review 30-05-2016,

Acceptance 13-06-2016, Published 12-07-2016.

Corresponding Author:

Dr. Abha Bharadwaja,

\#63, Ana Sagar Link Road,

Ajmer-305001,

Rajasthan.

E-mail:dr.abha@yahoo.co.in

DOI: $10.14260 /$ jemds $/ 2016 / 875$
The threshold limit value for formaldehyde is $0.3 \mathrm{ppm}$, which must never be exceeded. The legal permissible exposure limits are 0.75 average over an eight hour work shift and $2 \mathrm{ppm}$ not to be exceeded during 15 minute work period (Agency for toxic substance and Disease Registry 1999). WHO has developed a guideline for non-occupational exposure of formalin at $100 \mathrm{ppb}$ for 30 minutes so as to protect sensory irritation in general population.

\section{MATERIAL AND METHOD}

In the present study, effects of formalin on medical students of J.L.N. Medical College, Ajmer were evaluated. A questionnaire containing 15 questions based on the symptoms arising due to exposure to formalin was prepared and distributed to 50 students ( 25 male and 25 female).

The students were intimated about the purpose of study. Duly signed informed consent was taken thus eliminating the chances of participant bias. The students were in the age group 18-22, healthy, non-smoker with no H/o Cardiac, Pulmonary, Dermatological, or Epileptic disorder with no H/o previous exposure to formaldehyde fumes. There was no spillage of formalin in the lab. Condition of cadavers was good, so there was no leak of fluid from the cadavers. There was good ventilation in the dissection hall with proper exhaust facilities. The students were unconsciously routinely exposed to formaldehyde fumes during dissection hours ( 2 hours each day for 6 days a week).

The students were explained the symptoms and all the terms used were clarified. Symptoms were evaluated and grading was done (Grade 1 to 3 ) Grade 1 - never experienced, Grade 2 - experienced occasionally, Grade 3 - strong prominent and irritating.

\section{RESULT}

\begin{tabular}{|l|c|c|}
\hline \multicolumn{1}{|c|}{ Symptoms } & $\begin{array}{c}\text { Extent of } \\
\text { Symptom n }\end{array}$ & Percentage \% \\
\hline 1. Itching in Hands & 5 & 10 \\
\hline 2. $\begin{array}{l}\text { Itching before washing } \\
\text { hands with soap }\end{array}$ & 3 & 6 \\
\hline $\begin{array}{l}\text { 3. } \text { Itching after washing } \\
\text { hands with soap }\end{array}$ & 4 & 8 \\
\hline 4. Rashes & 5 & 10 \\
\hline
\end{tabular}




\begin{tabular}{|l|c|c|}
\hline $\begin{array}{l}\text { 5. Irritation on face and } \\
\text { neck area }\end{array}$ & 0 & 0 \\
\hline \begin{tabular}{l} 
6. $\begin{array}{l}\text { Sore nose/Running of } \\
\text { nose }\end{array}$ \\
\hline $\begin{array}{l}\text { 7. Redness/itching of } \\
\text { eyes }\end{array}$
\end{tabular} & 29 & 58 \\
\hline 8. Nausea/Vomiting & 13 & 26 \\
\hline 9. Headache & 13 & 26 \\
\hline 10. Sore/Dry throat & 7 & 14 \\
\hline 11. Fainting & 16 & 32 \\
\hline 12. GIT disturbances & 3 & 6 \\
\hline $\begin{array}{l}\text { 13. Respiratory } \\
\text { disturbances }\end{array}$ & 4 & 8 \\
\hline 14. Vertigo & 9 & 18 \\
\hline 15. Unusual disturbances & 6 & 12 \\
\hline
\end{tabular}

The table-1 shows the incidence of symptoms experienced by the medical students. Out of 50 students, 29 (58\%) were strongly affected by congestion/running nose and redness/itching of eyes. It is followed by soreness and dry throat in 16 (32\%). Headache, nausea, and vomiting was experienced by 13 (26\%) students.

\section{DISCUSSION}

First year medical students during their anatomy dissection classes are exposed to formaldehyde vapour. Exposure to these vapours is the cause of multiple chemical sensitivity. The present study shows the toxic effect to formaldehyde fumes arising from formaldehyde embalmed cadavers in the anatomy dissection hall.

Exposure to moderate levels of formaldehyde (1-3 ppm) can result in eye and upper respiratory tract irritation.(5,6,7) Exposure to more than $5 \mathrm{ppm}$ formaldehyde in air cannot be tolerated as its side effects increases and above $20 \mathrm{ppm}$ can lead to severe shortness of breath.(8,9) High concentration formaldehyde may result in nasal obstruction, chocking, dyspnoea, chest tightness, and pulmonary oedema.(10)

According to Ohmichi et al indoor concentration of formalin vapour depends on the contents and size of the dissection hall and seems to be increased when body cavity or deep structures are dissected.(11)

Wei et al observed that symptoms due to formalin exposure are dependent on time spent in dissection hall and suggested to reducing time spent while dissection could reduce symptoms.(12)

Since formaldehyde is toxic, search for alternative and safer fixative was done. Frolich et al in 1984 discovered nontoxic phenoxyethanol, but it took approximately 600 litres for fixing a cadaver and continuous immersion for 5-10 months was required thus eliminating its practical use.(13)

An aldehyde, Glutaraldehyde has fixative quality as formaldehyde, but as phenoxyethanol large quantities are required and is very expensive thus limiting its use.

Eisma et al used Thiel embalming, but again it was also expensive.(14)

Since formaldehyde is a gas present in formalin and its vapour are the toxic thus primary route of exposure is through respiratory system, eyes and skin, targeting nose, pharynx, larynx, trachea, lungs, eyes, and skin. Formaldehyde is water soluble thus it gets dissolved in mucosa and therein causes inflammatory changes and at times hyperplastic changes in mucosa.
Binding of formalin with endogenous proteins may result in formation of neoantigens, which may elicit an immune response leading to various symptoms produced.

In the US, the permissible limits of occupational exposure to formaldehyde are $3 \mathrm{ppm}$ in a time weight average breathing zone during a 8 hour period. A ceiling concentration of $5 \mathrm{ppm}$ and an acceptable maximum peak of $10 \mathrm{ppm}$ for no longer than 30 minutes during a one day shift.(15)

The most disturbing troublesome symptom appearing first was unpleasant smell of formalin. It can lead to headache, rhinitis, and dyspnoea. Prolonged exposure leads to mucous membrane irritation, burning, and lacrimation, lower respiratory effects like bronchitis, pneumonia, and pulmonary oedema. Sensitive individuals experience asthma and dermatitis even at very low doses. This observation also agrees with report from Japan.(16) where formaldehyde has been considered possible cause of nasopharyngeal tumours in humans and that is why Japan Ministry of Education, Culture, Sports, Science, and Technology (MEXT) has set guidelines, which recommends decreasing use of gaseous formaldehyde in gross dissection laboratories. Formaldehyde may also affect assimilation during dissection because when one is tired, dizzy, and has headache little or nothing can be grasped while dissecting.

Casanova-Schmitz et al (1984) reported predominant route of formaldehyde metabolism was metabolic incorporation into macromolecules (DNA, RNA, and proteins) in the respiratory and olfactory mucosa and bone marrow. The mechanism by which formaldehyde exerts its toxic effects is not known; however, it is known that formaldehyde readily combines with free unprotonated amino groups of amino acids and a protein, which is believed to be related to its germicidal properties. Higher concentration will precipitate proteins.(17,18) though none of the studies could identify target molecule.

\section{CONCLUSION}

Since our study is done among the students of same age group working in same environment thus individual variations were almost negligible. However, exact concentration of formaldehyde exposure cannot be determined or measured. Wei et al has shown that the subjective symptoms during the anatomy dissection course depends on the time spent in dissection hall, shorter time spent will have milder symptoms. First, MBBS students learn anatomy by doing dissection and it is an emotional challenge for them to overcome the biological effects of formaldehyde for that purpose it is suggested that:-

1. Those who are exposed to formalin should be aware of formalin inhalation.

2. There should be proper ventilation in the dissection hall. According to American Conference of Governmental Industrial Hygienist (2001), ventilation rate should exceed 15000 meter changes per hour (9).

3. Cadaveric waste should be disposed off properly in labelled plastic bags, which should be opened outside to avoid formaldehyde fumes exposure.

4. Medical professionals working in anatomy hall for long should use laboratory coats, goggles, and gloves.

5. Contact lenses should be avoided in dissection hall. 
6. Formalin collection containers beneath dissection table should be emptied and cleaned regularly.

7. Excess formalin spillage with in the dissection hall should be avoided.

8. Embalming should be done by trained professionals.

9. Pregnant medical professionals should avoid entry in dissection halls. If at all necessary should wear double mask and should not stay for more than one hour with 15 min breaks after each session.

10. Frolich et el in 1984 had tried phenoxyethanol instead of formalin. Glutaraldehyde (An aldehyde related to formaldehyde) was also tried, but both could not replace formalin as large volumes were needed.

Although, formalin has number of adverse effects and many medical professionals are unaware of them. Formaldehyde continues to be most potent agent used in embalming fluid as it is economical, excellent, preservative, and fixing solution. Hence, it should be used with proper monitoring and considering all its side effect.

\section{ACKNOWLEDGEMENT}

The authors are grateful to first MBBS students of JLN Medical College for their participation, support, and co-operation.

\section{REFERENCES}

1. Jain SR, Nahar PS, Baig MM. Study of formalin toxicity in I MBBS students. International Journal of Science and Research 2012;1(3):233-5.

2. Maibach H. Formaldehyde: effects on animal and human skin. In: Gibson J (ed). Formaldehyde toxicity. New York: Hemisphere Publishing 1983:166-74.

3. Patil GV, Kumar S, Thejeshwari, et al. Physical reactions of formalin used as cadaver preservative on first year medical students. Journal of evidence based medical and health 2014;5(5):279-83.

4. Onyije FM, Avwioro OG. Excruciating effect of formaldehyde exposure to students in gross anatomy dissection laboratory. The International Journal of Occupational and Environmental Medicine 2012;3(2): 92-5.

5. Weber-Tschopp A, Fisher T, Granjean E. Irritating effects of formaldehyde on men. Int Occup Environ Health 1977;39(4):207-18.
6. Green DJ, Sauder LR, Kulle TJ, et al. Acute response to 3.0ppm formaldehyde in exercising health non- smokers and asthmatics. Am Rev Respir Dis 1987;135(6):1261-6.

7. Feinman SE (edt). Formaldehyde sensitivity and toxicity. Boca Raton (FL): CRC Press Inc 1988.

8. Porter JAH. Acute respiratory distress following formalin inhalation. Lancet 1975;2:603-4.

9. Solomans K, Cochrane JWC. Formaldehyde toxicity part 1 occupational exposure and a report of 5 cases. S Afr MED J 1984;66:101-2.

10. Alexeeff GV, Budroe JD, Collins JF, et al. Determination of acute reference exposure levels for air borne toxicants. Acute toxicity, summary: formaldehyde 1999.

11. Ohmichi K, Komiyama M, Matsuno Y, et al. Formaldehyde exposure in a gross anatomt laboratory personal exposure is higher than indoor concentration. Environ Sci Pollut Res Int 2006;13(2):120-4.

12. Wei CN, Harada K, Ohmori S, et al. Subjective symptoms of medical students exposed to formaldehyde during a gross anatomy course. Int J Immuno pathol pharmacol 2007;20(2 Suppl 2):23-5.

13. Frolich KW, Endresen LM, Knutsen A, et al. Phenoxyethanol as a non-toxic substitute for formaldehyde in long term preservation of human anatomical specimens for dissection and demonstration purposes. Anat Rec 1984;208(2):271-8.

14. Eisma R, Lamb C, Soames RW. From formalin to thiel embalming what changes ? one anatomy department experiences. Clin Anat 2013;26(5):564-71.

15. Dixit D, Athavia PD, Pathak HM. Toxic effects of embalming fluid on medical students and professionals. JIAFM 2005;27(4):209-11.

16. Tanaka K, Nishiyama K, Yaginuma $H$, et al. Formaldehyde exposure levels and exposure control measures during an anatomy dissecting course. Kaibogaku Zassi 2003;78(2):43-51.

17. Toxicological profile for formaldehyde U.S department of health and human services public health service agency for toxic substances and disease registry, July 1999.

18. Casanova-Schmitz M, Raymond MD, Heck HD. Oxidation of formaldehyde and acetaldehyde by NAD department dehydrogenases in rat nasal mucosal homogenates. Biochem Pharmacol 1984;33(7):1137-42. 